\title{
Physicians' awareness and knowledge of medication-related osteonecrosis of the jaw
}

\section{Hekimlerin ilaç kullanımına bağlı çene osteonekrozu ile ilgili farkındalık ve bilgi düzeyleri}

\author{
Hamed Deveci ${ }^{1 *}\left(\mathbb{D}\right.$, Dilek Aynur Uğar Çankal ${ }^{2}$ \\ ${ }^{1}$ Uzm. Dt., Gazi Üniversitesi Diş Hekimliği Fakültesi, Ağız, Diş ve Çene Cerrahisi Anabilim Dalı, Ankara, Turkey \\ 2 Prof. Dr., Gazi Üniversitesi Diş Hekimliği Fakültesi, Ağız, Diş ve Çene Cerrahisi Anabilim Dalı, Ankara, Turkey \\ * Corresponding author: Hamed Deveci E-mail: hamed.rad34@gmail.com ORCID: 0000-0001-7670-6323 \\ Received: 11 September 2018 Accepted: 14 May 2018
}

\begin{abstract}
Increasing usage of bisphosphonates, denosumab, and other drugs with similar side effects, which are prescribed for osteoporosis, cancer-related metastases, and bone-related diseases such as Paget's disease, cause medication-related osteonecrosis of the jaw (MRONJ) cases to be encountered more frequently. Medical doctors and dentists who prescribe or employ these drugs must have comprehensive knowledge about the usage indications, mechanisms of action, and complications which may be caused by these drugs. However, there are few studies evaluating physicians' awareness of MRONJ. In this review, osteonecrosis, mechanisms of action, and complications which may be caused by bisphosphonates, denosumab, and other drugs with similar side effects are examined. Studies from various countries of the world related to the awareness of physicians who prescribe these drugs were reviewed for the purpose of this study. Also, the results of a study from the city of Ankara are presented.
\end{abstract}

Keywords: bisphosphonate, denosumab, osteonecrosis, awareness

() 2019 by the authors; licensee MEDITAGEM Ltd., Turkey. This article is an open access article distributed under the terms and conditions of the Creative Commons Attribution License (http://creativecommons.org/licenses/by/4.0/). 


\section{ÖZ}

Bifosfonat, denosumab ve benzer yan etkilere sahip ilaçların osteoporoz, kanser ile ilişkili kemik metastazları ve Paget hastalığı gibi kemik ile ilişkili hastalıklarda kullanımının artması hekimlerin çenelerde ortaya çıkan osteonekroz [ilaç kullanımına bağlı çene osteonekrozu (Medication-Related Osteonecrosis of the Jaws, MRONJ)] tablosu ile sıkça karşılaşmalarına neden olmaktadır. Bu durum özellikle söz konusu ilaçları reçete eden tıp hekimlerinin ve diş hekimlerinin ilaçların kullanım alanları, etki mekanizmaları, ortaya çıkabilecek komplikasyonları konusunda gerekli bilgi ve donanımına sahip olmalarını gerektirmektedir. Hekimlerin MRONJ ile ilgili farkındalığını değerlendiren az sayıda çalışma mevcuttur. Osteonekrozun, bifosfonat, denosumab ve benzer ilaçların etki mekanizmalarının ve yan etkilerinin anlatıldığı bu derlemede, bu ilaçları reçete eden hekimlerin farkındalıkları ile ilgili tüm dünyada yapılmış çalışmalar gözden geçirilmiş ve Ankara şehrinde yapılmış bir çalışmanın sonuçları sunulmuştur.

Anahtar kelimeler: bifosfonat, denosumab, osteonekroz, farkındalık

\section{INTRODUCTION}

Since the late $20^{\text {th }}$ century, medicines from the bisphosphonate group have been prescribed by physicians for the prevention and treatment of postmenopausal osteoporosis, hypercalcemia, bone-related conditions such as Paget's disease, cancers which metastasize to the lungs, prostate and breast cancers, and multiple myeloma [1].

Bisphosphonates are pyrophosphate analogues of inorganic pyrophosphates which contain a phosphorouscarbon-phosphorus group instead of a phosphorousoxygen-phosphorous group [2]. The basic biological effect of all bisphosphonates is the inhibition of bone resorption through osteoclasts and, thus, bone turnover and regeneration [3].

Over the past few years, antiresorptive and antiangiogenic medicines have also been used in addition to these medicines. Antibody-mediated antiresorptive therapy (AMART) uses monoclonal antibodies targeting molecular stabilizers involved in bone resorption pathways to stop both osteoporosis and metastatic bone diseases [4]. Of these medicines, denosumab is generally the first choice for treatment. It has been used since 2010 to prevent skeletal disorders and osteoporosis [4]. Denosumab suppresses both osteoporosis and skeletal-related events (SREs) in bone by inhibiting the receptor activator for nuclear factor kappa-B ligand (RANKL) $[4,5]$. For some medicines, Phase II and Phase III studies are in progress. Romosozumab is now in Phase III trials. Romosozumab functions by blocking sclerostin activity. Sclerostin suppresses bone formation by limiting osteoblast function [6]. Inhibition of proteases is also an effective way to prevent bone resorption. Odanacatib inhibits cathepsin $K$, which is a protease and causes the degradation of type I collagen. Therefore, this medicine protects the extracellular matrix [7].
Reports of osteonecrosis of jaw bones due to bisphosphonate usage was first published by Marx et al. in 2003 [8]. Until the report published in 2009 by the American Association of Oral and Maxillofacial Surgeons (AAOMS), there was no universally accepted definition of bisphosphonate osteonecrosis [1].

In the 2009 AAOMS guidelines, bisphosphonate-related osteonecrosis of the jaw (BRONJ) was defined as the presence of an eight-week long exposure of the bone of a patient who is using or has used bisphosphonates in the mandible or maxilla, but who was not treated with radiation therapy. However, the use of other medicine groups may cause osteonecrosis of the jaw and, therefore, cause a delay in recovery procedures in the jaw. The report published in 2009 was modified in 2014 to better distinguish this type of osteonecrosis seen in the jaw; it was named medicationrelated osteonecrosis of the jaw (MRONJ), and it constituted a new definition [9].

\section{PHYSICIANS' AWARENESS}

An increased awareness of the physicians who prescribe medications with bisphosphonates, denosumab, and other drugs having similar side effects, and dentists who provide oral care and treatment for their patients will prevent the uncontrolled use of these medicines and the risk of complications by insuring that these practitioners will take the necessary precautions before using them and, thus, will reduce the risk of MRONJ [10].

Currently, the increased use of bisphosphonates, denosumab, and other medicines with similar side effects often lead to cases involving osteonecrosis of the jaws. According to the Turkish Republic Ministry of Health Public Health Institution's 2015 data, deaths from cancer in Turkey accounted for $12 \%$ of all deaths in 2002 and rose to $20.7 \%$ in 
2014. If a similar increase occurs in cancer, it is expected that, by 2030 , there will be 22 million new cases per year, a $75 \%$ rate increase in new cases compared to the 2008 data [11]. According to the World Health Organization (WHO), in 2012, there were 14.1 million new cancer cases and 8.2 million cancer deaths in the world [12]. Parallel to this, it is predicted that the prescription rate of bisphosphonate, denosumab, and similar medicines will also increase. This means that the medical and dental practitioners who prescribe these medicines to patients need to have the necessary knowledge about the usage of these medicines, their mechanisms of action, and possible complications [10]. However, there exist very few studies evaluating physicians' awareness of and knowledge about MRONJ.

Raj et al. [13] conducted a survey of 136 medical practitioners, 283 dental practitioners, and 26 pharmacists registered in Victoria, Australia, and they reported that $88 \%$ of the medical doctors, $76 \%$ of the dentists, and $85 \%$ of the pharmacists were aware of jaw osteonecrosis. A total of $76 \%$ of the medical doctors and $100 \%$ of pharmacists stated that they were advising their patients to inform their dentists about it. Some medical doctors (45\%) guided their patients to dentists for a dental examination before starting bisphosphonate therapy, and $71.9 \%$ of the dentists reported that they had experienced this kind of guidance. The authors of the study proposed a common guideline on the subject because of the discrepancies in the understanding and procedures among the different health groups of practitioners.

In a study conducted by Alhussain et al. [14], a random webbased questionnaire was sent to 1,579 dentists in Ontario, Canada. The following information was gathered: bisphosphonate awareness, experience treating patients with jaw osteonecrosis, experience with various surgical procedures in patients receiving intravenous or oral bisphosphonates, and awareness of BRONJ regulation. The rate of response to questionnaire was $30 \%$. Of the responding physicians, $60 \%$ were found to have a good knowledge of bisphosphonates and BRONJ; however, only $23 \%$ reported that they were following surgical treatment guidelines for bisphosphonates, and $63 \%$ of the physicians stated that they had counseled patients with BRONJ. Approximately $50 \%$ of the responding dentists in Ontario stated that they were not comfortable treating BRONJ patients. The authors proposed that it might be beneficial to establish specific training strategies.

In 2010, López-Jornet et al. [15] conducted a survey in an autonomous community in Spain with 60 dentists and 60 dentistry students; the participants were asked questions about their knowledge, attitudes, and practices in respect to osteonecrosis of the jaw. Participants' knowledge of osteonecrosis associated with bisphosphonates was evaluated, and it was determined that 30 (50\%) of the students and 41 (68.36\%) of the dentists had up-to-date knowledge of the subject. Most were able to correctly identify the risk-related factors. Only eight (13.33\%) of the students and 20 (33.33\%) of the dentists stated that they did not know about osteonecrosis treatment. The authors proposed that training strategies related to BRONJ be established.

In a 2010 study conducted by Yoo et al. [16] in Korea, 264 dentists were surveyed about the AAOMS guidelines. The proportion of the dentists who knew the relationship between bisphosphonate use and osteonecrosis of the jaws was $56 \%$, while physicians reported that the rate of registering bisphosphonates for the anamnesis forms of the patients was $31.4 \%$. In the cross-sectional analysis, the recognition of the AAOMS directive was found to be very low. In terms of clinical experience, they reported that physicians with less than five years of clinical experience were more knowledgeable than doctors with more than five years of experience.

El Osta et al. [17] investigated the awareness and the level of knowledge of Lebanese physicians concerning BRONJ. They distributed 190 medical questionnaires, but only 136 physicians responded and participated in the survey. According to the cross-sectional descriptive study provided by the participation of specialist doctors from the Departments of Endocrinology, ENT, Gynecology, Internal Medicine, Maxillofacial Surgery, Nephrology, Oncology, Orthopedics, and Rheumatology, 85 of the participating physicians indicated that they applied bisphosphonate therapy, but the level of knowledge that such medicines prescribed by physicians had BRONJ complications was found to be inadequate.

Before applying any invasive treatment to a bisphosphonate-using patient, the dentists should consult the patient's physician regarding medication or dose adjustments and respond accordingly. Even though there is not a similar study to El Osta's in Turkey, it is believed that it is important for dentists to write detailed explanations of the consultations which need to be made, considering that medical doctors have a low awareness of MRONJ [10].

In a cross-sectional descriptive study conducted with a group of 222 physicians (endocrinologists: 6, oncologists: 5 , rheumatologists: 8 , maxillofacial surgeons: 5, dentists: 39 , 
orthopedic specialists: 25 , internal specialist: 25 , and family physicians: 109) in the Kingdom of Saudi Arabia, four questions were asked by Al-Mohaya et al. [18]. More than the half of the physicians prescribed bisphosphonates, but only $31.5 \%$ of these were aware of osteonecrosis of the jaw, and their BRONJ knowledge was inadequate.

In 2009, McLeod et al. [19] conducted a survey of 117 oral and maxillofacial surgery (OMFS) units in the United Kingdom (UK), and 63 replies were received. The units were surveyed as to how they managed patients presenting for treatment who had previously taken or were currently taking oral or parenteral bisphosphonates. Closed questions were asked regarding their use of chlorhexidine mouthwash, antibiotics, hyperbaric oxygen, and vasoconstrictors in local anesthetic solutions. Only $8 \%$ of the units which responded had a protocol for managing these patients. Current strategies for the prevention of bisphosphonate osteonecrosis include chlorhexidine mouthwash and pre- and post-operative antibiotics. The authors stated that establishing protocols related to the treatment of MRONJ could be important.

In a study [10] conducted in Ankara over a one-month period, 130 dentists participated in a web-based survey, and 173 dentists were interviewed face-to-face. Despite the fact that, 94.1\% (285 subjects) know that bisphosphonates, denosumab and other drugs with similar side effects may cause osteonecrosis of the jaws and 74\% appropriately answered question of "which jaw is more likely to be affected by osteonecrosis of the jaw"; only $6.6 \%$ correctly answered questions about the indications of such drugs. The correct response rate of $25 \%$ for the diagnosis of osteonecrosis decreased to $7.9 \%$ in the awareness of treatment approaches which may cause risks for the patients who are prescribed such medicines. As a result of these findings, it was suggested by the researchers that physicians should increase their knowledge about the subject.

\section{CONCLUSION}

As is the case in many developed countries, continuous education in Turkey will enable physicians to update their knowledge. Furthermore, it is considered that the awareness level of physicians can be increased through comprehensive study and dentistry training, publication of special editions related to this topic in journals, and organizing congresses and symposiums in the fields of medicine, dentistry, and pharmacology throughout Turkey [10].
Involvement in the medical profession implies a lifelong responsibility to continuously update knowledge, and physicians have no right to ignore this. Since medicine is an active field where constant developments, new therapies, medications, and applications occur daily, the main task of physicians is to follow these developments and continuously update their knowledge [10].

\section{DECLARATION OF CONFLICT OF INTEREST}

The authors received no financial support for the research and/or authorship of this article. There is no conflict of interest.

\section{REFERENCES}

1. Ruggiero SL, Dodson TB, Assael LA, Landesberg R, Marx RE, Mehrotra B. American Association of Oral and Maxillofacial Surgeons Position Paper on Bisphosphonate-Related Osteonecrosis of the Jaw-2009 Update. Aust Endod J. 2009; 35(3): 119-30.

2. McLeod NMH, Brennan PA, Ruggiero SL. Bisphosphonate osteonecrosis of the jaw: a historical and contemporary review. Surg. 2012; 10(1): 36-42.

3. Marx RE. Oral and intravenous bisphosphonate-induced osteonecrosis of the jaws. Chicago, III, USA Quintessence. $2007 ; 12$.

4. Farrier AJ, Franco LCS, Shoaib A, Gulati V, Johnson N, Uzoigwe $\mathrm{CE}$, et al. New anti-resorptives and antibody mediated anti-resorptive therapy. Bone Jt J. 2016; 98(2): 160-5.

5. Wang Z, Qiao D, Lu Y, Curtis D, Wen X, Yao Y, et al. Systematic literature review and network meta-analysis comparing bone-targeted agents for the prevention of skeletal-related events in cancer patients with bone metastasis. Oncologist. 2015; 20: 440-449.

6. Shah AD, Shoback D, Lewiecki EM. Sclerostin inhibition: a novel therapeutic approach in the treatment of osteoporosis. Int J Womens Health. 2015; 7: 565.

7. Rachner TD, Khosla S, Hofbauer LC. Osteoporosis: now and the future. Lancet. 2011; 377(9773): 1276-87.

8. Marx RE. Pamidronate (Aredia) and zoledronate (Zometa) induced avascular necrosis of the jaws: a growing epidemic. J Oral Maxillofac Surg. 2003; 61(9): 1115-7. 
9. Ruggiero SL, Dodson TB, Fantasia J, Goodday R, Aghaloo T, Mehrotra B, et al. American Association of Oral and Maxillofacial Surgeons position paper on medicationrelated osteonecrosis of the jaw-2014 update. J Oral Maxillofac Surg. 2014; 72(10): 1938-56.

10. Noury Rad Davaji H. How dentists in Ankara approach patients who use drugs that have side effects similar to biphosphonates, denosumab and etc. [Ankara]: Gazi University Faculty of Dentistry, Speciality Thesis. 2017.

11. Keskinkılıç B, Gültekin M, Karaca AS, Öztürk C, Boztaş G, Zayıfoğlu Karaca M, et al. editors. Turkey Cancer Control Programme. first ed. ANKARA: Republic of Turkey, Ministry of Health. 2016; p.18.

12. Cancer Fact Sheets: All Cancers Excluding NonMelanoma Skin Cancer [Internet]. International Agency for Research on Cancer, World Health Organization. 2016 [cited 2017 October 21]. Available at: http://gco.iarc.fr/today/data/pdf/fact-sheets/cancers/ca ncer-fact-sheets-29.pdf

13. Raj D V, Abuzar M, Borromeo GL. Bisphosphonates, healthcare professionals and oral health. Gerodontology. 2016; 33(1): 135-43.
14. Alhussain A, Peel S, Dempster L, Clokie C, Azarpazhooh A. Knowledge, practices, and opinions of ontario dentists when treating patients receiving bisphosphonates. J Oral Maxillofac Surg. 2015; 73(6): 1095-105.

15. López-Jornet $P$, Camacho-Alonso F, Molina-Miñano $F$, Gomez-Garcia F. Bisphosphonate-associated osteonecrosis of the jaw. Knowledge and attitudes of dentists and dental students: a preliminary study. J Eval Clin Pract. 2010; 16(5): 878-82.

16. Yoo J, Park Y, Kwon Y, Kim D, Ohe J. Survey of Korean dentists on the awareness on bisphosphonate-related osteonecrosis of the jaws. J Investig Clin Dent. 2010; 1(2): 90-5.

17. El Osta L, El Osta B, Lakiss S, Hennequin M, El Osta N. Bisphosphonate-related osteonecrosis of the jaw: awareness and level of knowledge of Lebanese physicians. Support Care Cancer. 2015; 23(9): 2825-31.

18. Al-Mohaya MA, Al-Khashan HI, Mishriky AM, Al-Otaibi LM. Physicians' awareness of bisphosphonates-related osteonecrosis of the jaw. Saudi Med J. 2011; 32(8): 8305.

19. McLeod NMH, Davies BJB, Brennan PA. Management of patients at risk of bisphosphonate osteonecrosis in maxillofacial surgery units in the UK. Surg. 2009; 7(1): 1823. 